\title{
Structural Features of Old Growth Forest from South Eastern Carpathians, Romania
}

\author{
Valentin Cristea ${ }^{1}$, Ștefan Leca ${ }^{2 *}$, Albert Ciceu ${ }^{2}$, Șerban Chivulescu ${ }^{2}$, Ovidiu Badea ${ }^{1,2}$
}

(1) Transilvania University of Brasov, Faculty of Silviculture and Forest Engineering, 1 Șirul Beethoven 1, RO-500123 Brasov, Romania; (2) National Institute for Research and Development in Forestry "Marin Drăcea", 28 Eroilor Blvd., RO-077190 Voluntari, Romania

* Correspondence: e-mail: stefan.leca@icas.ro

\begin{abstract}
Citation: CRISTEA V, LECA S, CICEU A, CHIVULESCU Ș, BADEA O 2019 Structural Features of Old Growth Forest from South Eastern Carpathians, Romania. South-east Eur for 10 (2): 159-164. DOI: https://doi. org/10.15177/seefor.19-13

Received: 24 May 2019; Revised: $10 \mathrm{Jul}$ 2019; Accepted: 11 Jul 2019; Published online: 15 Aug 2019
\end{abstract}

\begin{abstract}
Background and Purpose: Romania's forests are of globally significant value due to their natural characteristics, as similar forests in some other parts of the world have been lost forever. These types of forests, so-called "virgin" and "quasi-virgin (old growth)" forests, are also identified in the Buzau Mountains, which are part of the Eastern Carpathians in Romania (Curvature Region).

Materials and Methods: To study and understand the structure and dynamics of primeval forest, four permanent onehectare research plots were installed in the Penteleu Mountains, part of the Buzau Mountains. All trees with a diameter at breast height (DBH) greater than $80 \mathrm{~mm}$ were measured and their main dendrometric characteristics (DBH, height and social position) registered. The forest structure was analysed by fitting different theoretical distribution functions (beta, gamma, gamma 3P, gamma 3P mixt, loglogistic 3p, lognormal 3P and Weibull 3p). The structural homogeneity of the permanent research plots was tested using the Camino index $(H)$ and Gini index $(G)$.

Results: For the smaller DBH categories, Norway spruce was relatively shorter in height, but with increasing DBH, the heights of Norway spruce exceeded those of European beech. Stand volume varied between 615 and $1133 \mathrm{~m}^{3}$ per hectare. The area of maximum stability where we encountered the lowest tree height variability was recorded between the $60 \mathrm{~cm}$ and $100 \mathrm{~cm}$ diameter categories. The Lorenz curve and the Gini index indicated that the studied stands have high structural biodiversity.

Conclusions: The results showed that the studied forests have an optimal structural diversity, assuring them a higher stability and multifunctionality. Thus, these forests are models for managed forests.
\end{abstract}

Keywords: forest structure, quasi-virgin forests, old growth forests, DBH, optimal diversity, multifunctionality

\section{INTRODUCTION}

Romania's primary forests are of globally significant value due to their natural characteristics, as similar forests in some other parts of the world have been lost forever $[1,2]$. Quasi-virgin forests are those that have been managed in the past but that over time have been left to develop naturally, gaining specific features such as mixed tree ages, the presence of development phases, and strong relationships between dendrometric elements (i.e., diameter at breast height - DBH, height, and volume) $[3,4]$. The study of these forests is of high value, as they are considered an important source of scientific information that can be used in the management of unevenaged forests [5]. Quasi-virgin forests have numerous ecological, scientific, economic, social, and cultural characteristics, and they provide shelter for numerous species of flora and fauna [6] that have disappeared from managed forests.

Despite their importance, many quasi-virgin forests are partially or completely unprotected, and their surface area is decreasing. Given their importance, there is an urgent concern to protect all of these types of forests, in Romania as well as on a global scale [2,7]. Recently, interest in sustainable forest management concerning biodiversity and the protection of nature has increased enormously [8].

Numerous scientists have highlighted the importance of these types of ecosystems in different locations around the world [2]. In Europe, interest in natural forest stands began to appear with the publication of G. Gayer's Silviculture Treaty 
(1878), in which he proposed respecting natural laws in forest development. After World War II, Leibundgut carried out multiple studies in natural forest stands [9-11], promoting the importance of these special ecosystems at the International Union of Forest Research Organizations (IUFRO). In 1971, IUFRO established a research group focused on studying natural forest stands and, taking into account the remarkable results and work done by Leibundgut, appointed him chairman of this scientific group [12]. In the period from 19951999, research was carried out within the secular forest stands situated in the boreal area of the Scandinavian Peninsula and in the northern European region of Russia, which exhibited the dangers of forest loss due to excessive logging [13]. Other studies of this kind were carried out in the Perućica Forest Reserve in the territory of Bosnia and Herzegovina; that work concluded that these natural forests are clearly superior in terms of biodiversity and structure compared to managed forests [14]. In 2000, a research area of 10 hectares was installed in the Uholka-Shyrokyi Luh Reserve (total area of the reserve is 15,974 ha, of which approx. 9,000 ha are considered virgin beech forests) located in the Transcarpathian region of Ukraine [15]. The naturalness, uniqueness, and the high level of biodiversity of these forests have attracted the attention of politicians and led to changes in the legislative framework in order to better protect them [12]. In Croatia, laws adopted for the protection and maintenance of natural forests date back to the 18th century [16]. In Romania, quasi-virgin forests have been protected by modifying the legal framework [17]. The aim of this paper is to emphasize the structural characteristics and very high structural diversity of quasi-virgin forests located in the Curvature Carpathians region (Romania) and to highlight the knowledge of their special structural features. The results of research on primary forests are extremely valuable for developing sustainable forest management practices.

\section{MATERIALS AND METHODS}

Four permanent research plots (Plots A, B, C and D) were established in the Penteleu Mountains in the Curvature Carpathians Region, Romania (Figure 1).

The forest stands where the permanent research plots were located have not been influenced by human activity for a very long time, according to the criteria for identifying quasi-virgin forests $[17,18]$. The permanent research plots were established during the period 2015-2018 and have dimensions of $100 \times 100 \mathrm{~m}$ (1 ha). The perimeter of each plot was delineated using a Global Positioning System (GPS). All trees in each permanent research plot with a $\mathrm{DBH}>8 \mathrm{~cm}$ were inventoried by measuring the $\mathrm{DBH}$ and height $(\mathrm{H})$ and establishing the tree's social position in the canopy. Tree height was measured using an ultrasonic hypsometer (Vertex IV) and DBH using a measuring tape. Based on the field inventory of the forest stands, their structural characteristics were processed and analysed. First the DBH distribution was analysed, then the structural biodiversity of the studied forest stands. It has been established that in the absence of human intervention, natural dynamics lead to very diverse forest stand structures $[19,20]$. One of the important aspects of diversity in forests is tree size variability. Gini [21] and Camino [22] are two relevant indices of forest structure based on dispersion estimates of tree size [20]. The structural homogeneity of the studied forest plots was tested using the Camino and Gini indexes, and a graphic representation was made using the Lorenz curve [23]. The Gini coefficient has proven to perform better as an indicator of forest structure than Shannon's diversity index, Simpson or other indices [24]. Therefore, the Gini coefficient is recognised as the best estimator of stand structure based on DBH $[25,26]$.

The volume of each tree was determined using the following formula:

$$
\log v=b_{0}+b_{1} \log d+b_{2} \log ^{2} d+b_{3} \log h+b_{4} \log ^{2} h
$$

where $b_{0}, b_{1}, b_{2}, b_{3}$ and $b_{4}$ are nationally (Romanian) specific coefficients for each species. The experimental DBH distribution was fitted using different theoretical distribution functions (beta, gamma, gamma 3P, gamma $3 \mathrm{P}$ mixt, loglogistic 3p, lognormal $3 \mathrm{P}$ and Weibull $3 p)$. To estimate the goodness of fit of the theoretical distributions to the measured $\mathrm{DBH}$ values, the $\chi 2$ criterion, Kolmogorov Smirnov (KS) [28] and Anderson Darling (AD) [29] statistical tests were used. Analyses were performed using Microsoft Excel Software, Mathwave - EasyFit Distributions, IBM SPSS Statistics, and packages fitdistrplus [30] and mixdist [31] of the software R.

\section{RESULTS AND DISCUSSION}

All the permanent research plots exhibited uneven-aged structure, a large number of trees and a high volume per hectare (Table 1).

Fitting of Experimental DBH Distribution Related to Number of Trees

To identify the best theoretical function to fit the distribution of the collected field data, beta, gamma, gamma

TABLE 1. General characteristics of permanent research plots.

\begin{tabular}{|c|c|c|c|c|c|c|}
\hline $\begin{array}{l}\text { Research } \\
\text { Plot }\end{array}$ & $\begin{array}{c}\text { Altitude } \\
(\mathrm{m})\end{array}$ & $\begin{array}{c}\text { Area } \\
\text { (ha) }\end{array}$ & Shape & $\begin{array}{c}\text { Stand } \\
\text { structure }\end{array}$ & $\begin{array}{l}\text { No. } \\
\text { of trees per ha }\end{array}$ & $\begin{array}{l}\text { Volume } \\
\left(\mathrm{m}^{-3} \cdot h \mathrm{a}^{-1}\right)\end{array}$ \\
\hline Plot A & 1130 & 1 & square & uneven - aged & 612 & 1133.34 \\
\hline Plot B & 1100 & 1 & square & uneven - aged & 749 & 785.44 \\
\hline Plot C & 1250 & 1 & square & uneven - aged & 522 & 910.25 \\
\hline
\end{tabular}




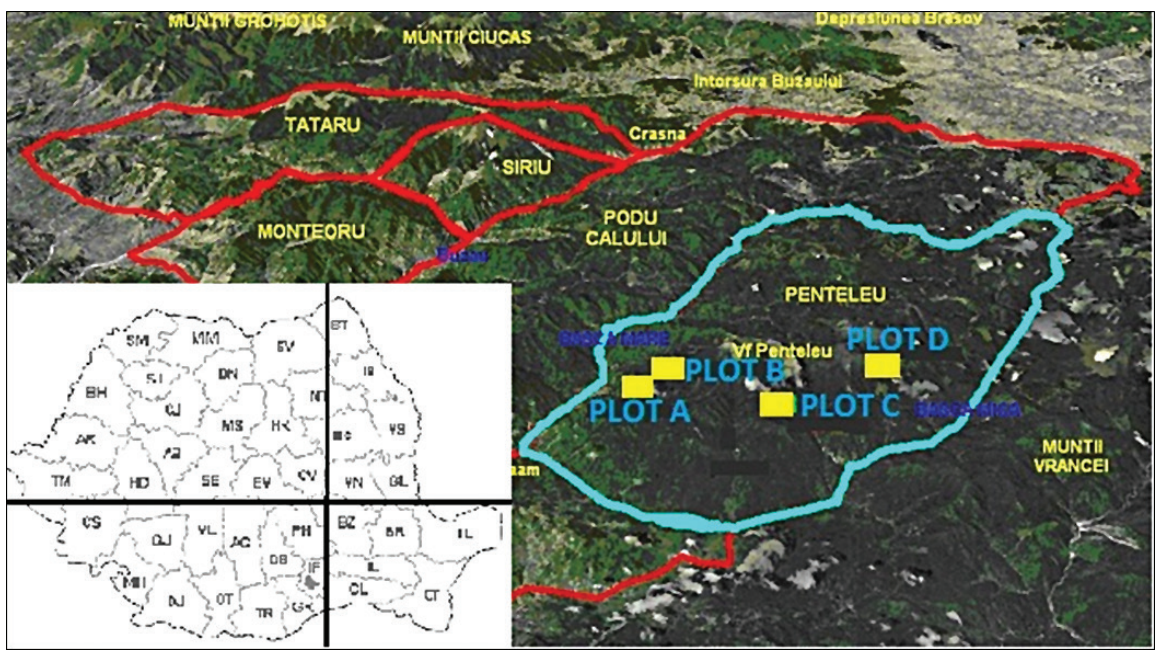

FIGURE 1. Research plots location (www. fetch.ro).

3P, gamma 3P mixt, loglogistic 3p, lognormal 3P and Weibull $3 p$ functions were tested (Figure 2). In the case of research plot C, a bimodal experimental distribution was observed. For this particular situation where the forest stand could not be fitted with the studied theoretical functions, a combination of two gamma functions was used. The bimodal distribution is more accentuated in research plot $\mathrm{C}$ than in the other plots and is related to the plot's history $[32,33]$ and events like fire [34], wind disturbance or other biotic and abiotic factors.

The KS test and $\chi^{2}$ criterion for goodness of fit for plot A showed no differences between the experimental and theoretical distributions for the lognormal 3P function. The $A D$ test showed no differences between the experimental and theoretical distributions for the Weibull $3 \mathrm{P}$, gamma $3 \mathrm{P}$ and lognormal 3P functions. In the case of plot B, all of the goodness of fit tests indicated that the experimental $\mathrm{DBH}$ distribution followed the theoretical distributions except for the gamma distribution, where the statistical tests showed significant differences between the experimental and theoretical distributions. In the case of plot $D$, the relationship between $\mathrm{DBH}$ distribution and number of trees was analysed using the lognormal 3P, gamma $3 \mathrm{P}$ and beta functions. None of these theoretical functions adjusted the experimental DBH distribution (Table 2). Using the $\chi^{2}$ criterion, in the case of plot $C$, the theoretical frequencies resulting from the mixed gamma $3 \mathrm{P}$ function were significantly different from the experimental distribution ( $p>0.05$ ) (Table 3). The experimental DBH distribution has a descending form, with the highest numbers of trees in small DBH categories and a shape similar to a reverse "J" [35], which is specific to the structure of quasi-virgin forests. All research plots exhibited high variation in $\mathrm{DBH}$, over $90 \mathrm{~cm}$, an aspect specific to uneven-aged stands [36, 37].

Structural Biodiversity Analysis of Studied Forest Stands

To test the biodiversity of the studied stands, the Gini (G) and Camino $(\mathrm{H})$ indexes were calculated, and for graphical analysis, a Lorenz curve was generated (Figure 3). The Lorenz

TABLE 2. Main indicators of theoretical distributions.

\begin{tabular}{|c|c|c|c|c|c|c|c|}
\hline \multirow{2}{*}{$\begin{array}{l}\text { Research } \\
\text { plot }\end{array}$} & \multirow{2}{*}{ Distribution } & \multicolumn{2}{|c|}{ Kolmogorov Smirnov Test } & \multicolumn{2}{|c|}{ Anderson Darling Test } & \multicolumn{2}{|c|}{$\chi 2$ Criterion } \\
\hline & & $\begin{array}{c}\text { Experimental } \\
\text { values }\end{array}$ & $\begin{array}{c}\text { Theoretical } \\
\text { values }\end{array}$ & $\begin{array}{c}\text { Experimental } \\
\text { values }\end{array}$ & $\begin{array}{c}\text { Theoretical } \\
\text { values }\end{array}$ & $\begin{array}{c}\text { Experimental } \\
\text { values }\end{array}$ & $\begin{array}{c}\text { Theoretical } \\
\text { values }\end{array}$ \\
\hline \multirow{3}{*}{ Plot A } & Weibull 3p & 0.06 & 0.054 & $2.47^{*}$ & 2.50 & 25.76 & 16.92 \\
\hline & Lognormal 3p & $0.05^{*}$ & 0.054 & $2.05^{*}$ & 2.50 & $13.21 *$ & 16.92 \\
\hline & Gamma 3p & 0.06 & 0.054 & $2.33^{*}$ & 2.50 & 25.17 & 16.92 \\
\hline \multirow{3}{*}{ Plot B } & LogLogistic 3p & $0.04 *$ & 0.049 & $1.99 *$ & 2.50 & $8.02 *$ & 16.92 \\
\hline & Lognormal 3p & $0.03 *$ & 0.049 & $1.38^{*}$ & 2.50 & $10.71 *$ & 16.92 \\
\hline & Gamma & 0.15 & 0.049 & 22.46 & 2.50 & 130.91 & 16.92 \\
\hline \multirow{3}{*}{ Plot D } & Lognormal 3p & 0.07 & 0.057 & 5.22 & 2.50 & 38.47 & 16.92 \\
\hline & Beta & 0.09 & 0.057 & 5.74 & 2.50 & 48.39 & 16.92 \\
\hline & Gamma 3p & 0.09 & 0.057 & 5.57 & 2.50 & 49.42 & 16.92 \\
\hline
\end{tabular}




\section{Research plot (A)}

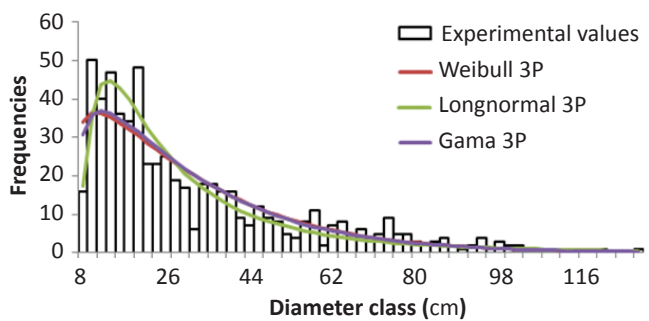

Research plot (C)

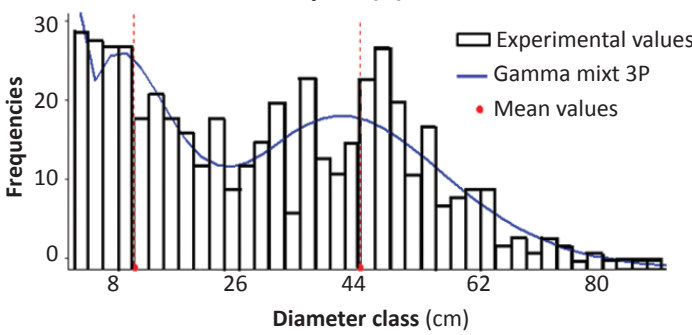

Research plot (B)

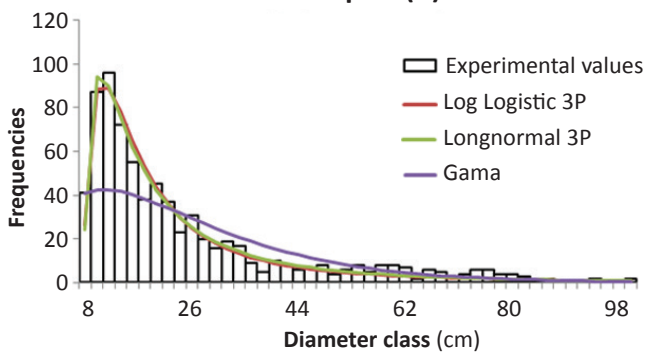

Research plot (D)

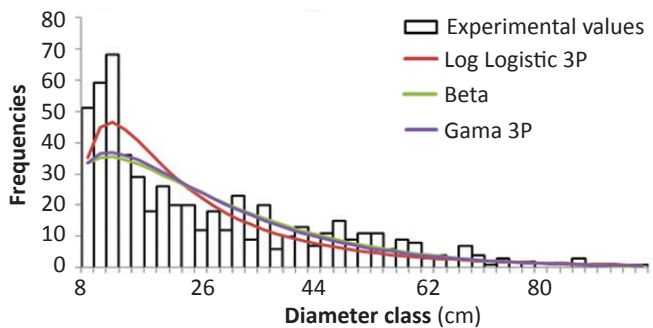

FIGURE 2. Fitting experimental (observed) DBH distributions with theoretical functions.

curve and the Gini indexes indicate that the studied stands have high structural biodiversity, which is specific to this type of forest ecosystem. The Gini index of the plots ranged from 0.69-0.71 which is very close to the index's maximum value of 1 [24]. The Camino index of the plots ranged between 1.62 and 1.71. The Gini and Camino coefficients calculated for the
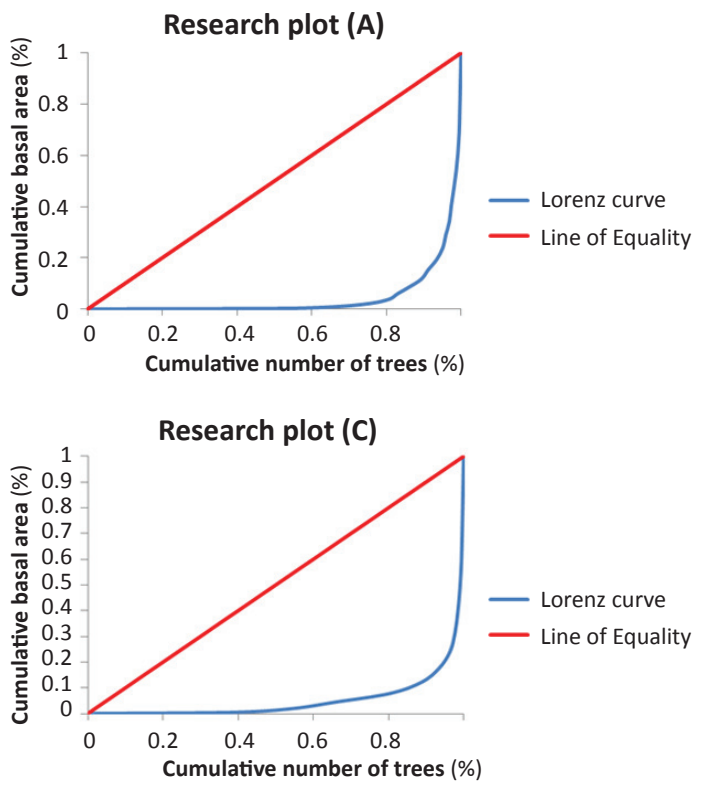

FIGURE 3. Lorenz Curve for each permanent research plot.
TABLE 3. The results of the statistical test $\chi 2$ used to fit experimental distribution with Gamma mixt function in research plot $\mathrm{C}$.

\begin{tabular}{ccccc}
\hline Research plot & Function & $\mathbf{f}$ & $\boldsymbol{\chi 2}$ & $\mathbf{p}$ \\
\hline Plot C & Gamma & 42 & 48.567 & 0.2254 \\
\hline
\end{tabular}

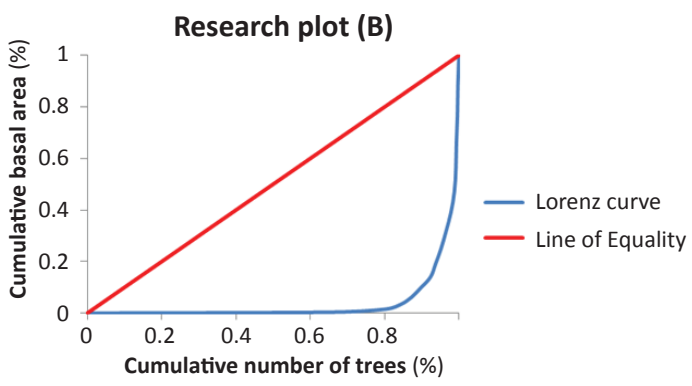

Research plot (D)

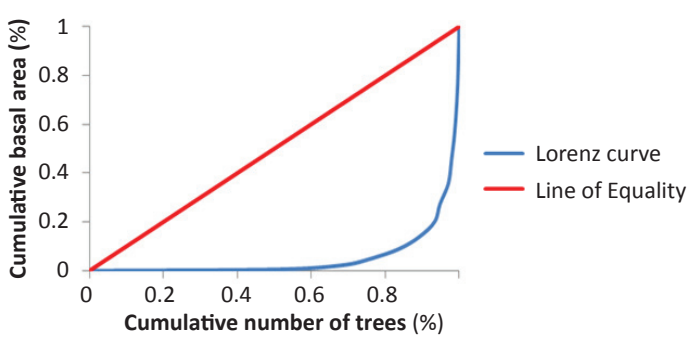


forest stands in the present research are close to the values obtained for other uneven-aged forests, which emphasizes that the studied stands are characterized as uneven-aged stands [38-40].

\section{CONCLUSIONS}

Based on the results presented in this research, it can be concluded that due to their structural complexity, quasivirgin forests represent a very good scientific base for studying the natural structure and dynamics of a forest, and can be considered as "real laboratories in situ". The presence of large-DBH trees and fast development phase alternations are signs of strong dynamics as well as a great capacity to regenerate after natural competition processes.

The protection of quasi-virgin forests should be a precondition for successful scientific research in natural science. To develop improved forest management practices, it is very important to understand the structural principles and development of natural forests. The legislative system in Romania for protection of natural areas where we still encounter natural ecosystems that are not influenced by humans must generally be improved, and very valuable quasi-virgin forest areas must be included among other natural conservation areas.

\section{REFERENCES}

1. REININGER H 1997 Romanian old growth forest, archetype for an ecological silviculture (in romanian). In: Forest magazine. Romsilva, Bucharest, Romania, pp 92-94

2. GIURGIU V 2013 Virgin and quasi - virgin forests of Romania (in romanian). Romanian Academy Publishing Home, Bucharest, Romania, $390 \mathrm{p}$

3. ROMANIAN FOREST RESEARCH AND MANAGEMENT INSTITUTE 2005 Virgin forests in Romania: inventory and strategy for sustainable management and protection of virgin forests in Romania. URL: http://www.greenpeace. org/romania/Global/romania/paduri/2015-12-22 Virgin forest Romania Summary.PDF (25 March 2019)

4. WIRTH C, MESSIER C, BERGERON Y, FRANK D, FANKHÄNEL A 2009 Old- Growth Forest Definitions: a Pragmatic View. In: Old - Growth Forests Function, Fate and Value, SpringerVerlag, Berlin, Germany, pp 11-33

5. CHIVULESCU S, BADEA O, TOMESCU R, SILAGHI D, LECA S, TURCU D 2014 Structural features of virgin beech forests in Semenic mountains. The dynamic structure of virgin beech forest P20 Semenic between 2005-2013. Proceedings of Romanian Academy-Series B: Chemistry, Life Science and Geoscience 16 (2): 115-124

6. TOMESCU R, TÂRZIU D, TURCU D 2013 Contributions to knowledge of virgin beech structure dynamics from Izvoarele Nerei - Semenic Natural Reservation (in romanian). In: Giurgiu V (ed): Virgin and quasi - virgin forests of Romania. Romanian Academy Publishing Home, Bucharest, Romania, pp 209-257

7. GILG O 2004 Old-Growth forest: characteristics, conservation and monitoring. Habitat and species management. Techn. Report 74, Montpellier, France, $96 \mathrm{p}$

8. CHIVULESCU S, LECA S, SILAGHI D, BADEA O 2016 Growth of virgin forests in the southern Carpathians. Agriculture and Forestry 62 (3): 39-48. DOI: https://doi.org/10.17707/ AgricultForest.62.3.03

9. LEIBUNDGUT H 1959 Purpose and methodology of structural analysis and growth of virgin forests (in German). Schweiz Zeitschr f Forstwesen 110 (3): 111-124

10. LEIBUNDGUT H 1978 About the dynamics of European virgin forest (in German). Allg Forstzeitschr 24: 686-690

11. LEIBUNDGUT H 1982 European primary forests of Bergstufe: presented for foresters, scientists and forest friends (in German). Haupt, Bern-Stuttgart, Zwitzerland Germany, $308 p$
12. SCHUCK A, PARVIAINEN J, BÜCKING W 1994 A Review of Approaches to Forestry Research on Structure, Succession and Biodiversity of Undisturbed and Semi - Natural Forests and Woodlands in Europe. European Forest Institute, Joensuu, Finland, $71 \mathrm{p}$

13. AKSENOV D, KARPACHEVSKIY $M$, LLOYD S, YAROSHENKO A 1999 The Last of the Last: The Old-growth Forests of Boreal Europe. Taiga Rescue Network, Moskow, Russia, $63 \mathrm{p}$

14. PINTARIĆ K 1999 Forestry and Forest Reserves in Bosnia and Herzegovina. In: Diaci J (ed) Virgin forests and forest reserves in central and east European countries. Department of Forestry and Renewable Forest Resources Biotechnical Faculty, Ljubljana, Slovenia, pp 1-15

15. COMMARMOT B, BUNDZIAK $Y$, BACHOFEN $H$, BÜRGI A 2005 Structure of virgin and managed beech forests in Uholka (Ukraine) and Sihlwald (Switzerland). Forest Snow and Landscape Research 79 (1): 45-56

16. MATIĆ S 1999 The forests of Croatia - country report. In: Diaci J (ed) Virgin forests and forest reserves in central and east European countries. Department of Forestry and Renewable Forest Resources - Biotechnical Faculty, Ljubljana, Slovenia, pp 17-24

17. THE MINISTRY OF ENVIRONMENT AND FORESTRY 2012 Establishing criteria and indicators for identifying virgin and quasi-virgin forests (in Romanian). Official Monitor 668, Bucharest, Romania. URL: http://legislatie.just.ro/ Public/DetaliiDocument/141475.html (28 March 2019)

18. FRELICH LE, REICH PB 2003 Perspectives on development of definitions and values related to old-growth forests. Environ Rev 11 (S1): 9-22. DOI: https://doi.org/10.1139/ a03-011

19. HETT JM, LOUCKS OL 1976 Age structure models of Balsam Fir and Eastern Hemlock. J Ecol 64: 1029-1044. DOI: https://doi.org/10.2307/2258822

20. VALBUENA R, PACKALÉN P, MARTI S, MALTAMO M 2012 Diversity and equitability ordering profiles applied to study forest structure. Forest Ecol Manag 276: 185-195. DOI: https://doi.org/10.1016/i.foreco.2012.03.036

21. CERIANI L, VERME P 2012 The origins of the Gini index: extracts from Variabilità e Mutabilità (1912) by Corrado Gini. J Econ Inequal 10 (3): 421-443. DOI: https://doi. org/10.1007/s10888-011-9188-x

22. DE-CAMINO R 1976 Determination of the homogeneity of stands (in Spanish). Bosque 1 (2): 110-115 
23. LORENZ MO 1905 Methods of measuring the concentration of wealth. Publ Am Stat Assoc 9 (70): 209-219. DOI: https:// doi.org/10.2307/2276207

24. DUDUMAN G $2011 \mathrm{~A}$ forest management planning tool to create highly diverse uneven-aged stands. Forestry 84 (3): 301-314. DOI: https://doi.org/10.1093/forestry/cpr014

25. ICHIM R 1968 Research on the precision of cubing methods applied in the spruce stands in relation to the variability of trees shape (in Romanian). PhD thesis, Polytechnic Institute, Brasov, Romania, $192 \mathrm{p}$

26. KLOPČIČ M, BONČINA A 2011 Stand dynamics of silver fir (Abies alba Mill.)-European beech (Fagus sylvatica L.) forests during the past century: a decline of silver fir? Forestry 84 (3): 259-271. DOI: https://doi.org/10.1093/ forestry/cpr011

27. GIURGIU V 1979 Dendrometry and forest auxology (in Romanian). Ceres, Bucharest, Romania, $691 \mathrm{p}$

28. STEPHENS MA 1979 Tests of Fit for the Logistic Distribution Based on the Empirical Distribution Function. Biometrika 66 (3): 591-595. DOI: https://doi.org/10.1093/ biomet/66.3.591

29. ANDERSON TW, DARLING DA 1954 A Test of Goodness of Fit. J Am Stat Assoc 49 (268): 765-769

30. DELIGNETTE ML, DUTANG C, POUILLOT R., DENIS JB 2019 Help to Fit of a Parametric Distribution to Non-Censored or Censored Data R package. URL: https://rdrr.io/cran/ fitdistrplus/ (2 April 2019)

31. MACDONALD P, DU J 2018 Finite Mixture Distribution Models R package version 0.5-5. URL: https://cran.rproject.org/web/packages/mixdist/mixdist.pdf (3 April 2019)

32. KARJALAINEN L, KUULUVAINEN T 2002 Amount and diversity of coarse woody debris within a boreal forest landscape dominated by Pinus sylvestris in Vienansalo wilderness, eastern Fennoscandia. Silva Fenn 36 (1): 147167. DOI: https://doi.org/10.14214/sf.555
33. ROUVINEN S, KUULUVAINEN T 2005 Tree diameter distributions in natural and managed old Pinus sylvestrisdominated forests. Forest Ecol Manag 208 (1-3): 45-61. DOI: https://doi.org/10.1016/i.foreco.2004.11.021

34. ENGELMARK O, HOFGAARD A, ARNBORG T 1998 Successional trends 219 years after fire in an old Pinus sylvestris stand in northern Sweden. J Veg Sci 9 (4): 583592. DOI: https://doi.org/10.2307/3237274

35. WESTPHAL $\mathrm{C}$, TREMER N, VON OHEIMB G, HANSEN J, VON GADOW K, HÄRDTLE W 2006 Is the reverse J-shape diameter distribution universally aplicable in European virgin beech forests? Forest Ecol Manag 223 (1-3): 75-83. DOI: https://doi.org/10.1016/i.foreco.2005.10.057

36. SCHÜTZ JP 2001 The selection forest and other forms of structured and mixed forests (in german). Parey, Berlin, Germany, $240 p$

37. BONCINA A 2011 History, current status and future prospects of uneven-aged forest management in the Dinaric region: an overview. Forestry 84 (5): 467-478. DOI: https://doi.org/10.1093/forestry/cpr023

38. ROIBU CC, TOMESCU C, SAVIN A, MIRON-ONCIUL M 2008 Analysis of biodiversity regarding structural and phytocoenological aspect in "old growth beech forest of Humosu" Reservation. Romanian Academy Journal 2: 2531

39. CENUȘĂ R, POPA C, TEODOSIU M 2002 Researches on the structure-function relationship and the evolution of natural forest ecosystems in the north of the country (in Romanian). Ann For Res 45 (1): 9-20

40. DUDUMAN G 2009 The ecological foundation of the calculation of the possibility in forests treated in the garden gardening (in Romanian). University of Suceava Publishing House, Suceava, Romania, $300 \mathrm{p}$ 